\title{
WTO and India's Agricultural Trade Potential
}

\section{Raghav Bansal ${ }^{a}$, Nitesh Khandelwal ${ }^{\text {b }}$, Surmya Maheshwaric, Dr. Hari Prapan Sharmad}

aStudent of BA Economics (H) IIIrd Year, Institute of Business Management, GLA University, Mathura, India.

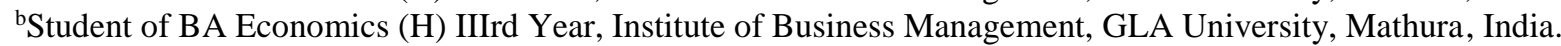
'Student of BA Economics (H) IIIrd Year, Institute of Business Management, GLA University, Mathura, India. dAssistant Professor, Institute of Business Management, GLA University, Mathura, India.

dE-mail: hari.sharma@gla.ac.in

Article History: Received: 11 January 2021; Accepted: 27 February 2021; Published online: 5 April 2021

\begin{abstract}
India is an agrarian economy, which contributes about 15 percent of GDP and provides livelihood to more than 50 percent of the total population of the country. WTO has shown a momentous part in the expansion of the export market for developing and developed economy. Several measures are taken by WTO in order to reduce trade restrictions and trade barriers. In this study, we have been analyzed India's agriculture trade, composition, direction and potential. The study is dependent on secondary data which is gathered from International Trade Centre, Department of Agriculture and Cooperation. Two-digits HS code products range from 01-24 were taken for the study. Few specific two and four-digit HS code products were taken to analyze the Revealed Comparative Advantage (RCA). Data were taken for the period 2001-2018. The export potential of India in international market was identified using reckoning of Balassa's index of RCA. Study reveals that there has been a positive agricultural trade balance since 1990-91. In some agriculture commodities like coffee, oilseeds, tea and wheat India has a comparative advantage in export and India have both developed and developing countries such as UAE, USA, Saudi Arabia, Vietnam and Iran are exporting partner. In the last, study suggest that the government of India should focus more on producing agriculture products which has a country comparative advantage in trade like tea, oilseeds, coffee and wheat. Study suggests that EXIM bank should provide adequate credit to encourage agricultural export. The farming should be export-oriented to meet international standards.
\end{abstract}

Keywords: Revealed Comparative Advantage, HS Code, Agriculture Trade, Composition, Direction, Potential.

\section{Introduction}

India is an agrarian economy, which contributes about 15 percent in GDP. This number is not massive because the growth rate of other sectors has been remaining better in last two decades however its significance in the economy cannot be denied because. It provides livelihood to more than 50 percent of the total population of the country. Nearly 70 percent of the total population of the country depends on rural income as the majority poor population is found in rural areas. Agriculture is indisputably the largest livelihood provider in India. Agriculture has witnessed many revolutions over the time since independence; the revolutions are the Green revolution, a yellow revolution, a blue revolution, and a white revolution, which makes India as self-sufficient in food provision to its population. India's food security depends on the production of fruits, milk, vegetables and cereal crops in order to fulfill the demand of increasing population of the country with increasing incomes. In order to fulfill this, there is a need to accelerate the pace of an aggressive, sustainable, diversified and productive agricultural sector.

India is considered as a global agricultural powerhouse. Milk, spices and pulses are the goods that India produce maximum with respect to the world. India has the largest cattle herd in the world, and also has the largest area for wheat, cotton and rice. Despite having huge area for cotton, wheat and rice, India is still comes second in the list to produce them. India is also second largest producer in sheep \& goat meat, tea, vegetables, farmed fish, sugarcane and vegetables. We are going to study the potential of Indian agriculture in world market and for this; we would find the Revealed Comparative Advantage (RCA).

David Ricardo, an English Economist of the $19^{\text {th }}$ century, gave a concept with the name of it being Comparative Advantage Theory. He considered that the output of the world would increase more than the output they would generate individually once the principle of comparative advantage is implemented by countries for the determination of the goods and services they should get specialized in producing. He recommended that the countries should get specialized by allocating their limited resources to produce the goods and services for which they have a Comparative Cost Advantage.

WTO played a momentous role in the expansion of the export market for developing and developed economy. WTO study states that the developing countries would be protected from getting exploited in the international trade market. The study has given the ideology of WTO in promoting ideal trade. The idea of this study is to show how the trade potential of the country can increase for the agricultural commodities through 
RCA. The study further reveals that it examines the requirement of growth of major agricultural commodities for exports

The growth of the economy or the different sectors of the country depends on how the India agriculture performs (Tripathi and Prasad, 2009). Thus, for decreasing poverty through economic development, a living and growing agricultural sector is important (Ingco and Nash, 2004). The contribution of agrarian sector in Indian economy is constantly decreasing, but still contributes about 15 percent of GDP (2018-2019). A decline of agriculture GDP is the outcome of economic advancement (Byerlee et al., 2009). For becoming self-sufficient in the production of food grains, green revolution had played a very crucial role for India.The food grains have increased from 50.82 Million Tonnes (1950-51) to 277.49 Million Tonnes (2017-18) (Department of agriculture, GOI). Due to rise in domestic demand because of increase in population growth, India's agriculture export declined however, India still has a large potential in exports. There were more fluctuations in the agricultural trade in India than the trade in other sectors (Panchamukhi, 1986).

World Trade Organization played a vital part in the expansion of the export market for developing and developed economy. Several measures are taken by WTO in order to reduce trade restrictions and trade barriers. After all contraction in trade restrictions, competition has increased. In this study, India's agriculture trade, composition, direction and potential has been analyzed in post WTO period. There are also some suggestions on policy measures for agricultural trade development.

\title{
2. Research Methodology
}

The study is dependent on secondary data which is taken from International Trade Centre, Department of Agriculture and Co-operation; and Economic Survey. Two-digits HS code products range from 01-24 were taken for the study. Few specific two and four-digit HS code products were taken to analyze the Revealed Comparative Advantage (RCA). Data were taken for the period 2001-2018.

\section{Analytical Analysis}

The export potential of India in international market was identified using the calculations of Balassa's index. In 1965, Balassa resulted an index which is used to assess a country's Comparative Advantage called the Balassa's Index. The index does not target to identify or determine the primary sources of comparative advantage but tries to classify whether a country has a "Revealed" Comparative Advantage (Utkulu \& Seymen, 2004). Comparative Advantage of a country is "Revealed" if RCA > than unity. India is believed to have a Comparative Disadvantage if RCA value is less than unity. There is a possibility of agricultural trade among India and rest of the world if RCA > unity.

$$
R_{i h}=\frac{X_{i h}}{X_{i t}} / \frac{X_{w h}}{X_{w t}}
$$

\section{Balassa's Revealed Comparative Advantage Index (RCA)}

\author{
$\mathbf{R}_{\mathbf{i h}}=$ Balassa's index of RCA \\ $\mathbf{X}_{\text {ih }}$ = India export of commodity $\mathrm{h}$ \\ $\mathbf{X}_{\mathbf{i t}}=$ Total export of India \\ $\mathbf{X}_{\mathbf{w h}}=$ World export of commodity $\mathrm{h}$ \\ $\mathbf{X}_{\mathbf{w t}}=$ Total world export
}

\section{RCA Index}

The concept of specialization includes heavy focus on one area activity and less focus on another area. RCA does not measure international competitiveness; it measures international specialization of a country in a particular sector. The potential of the country is not measured in absolute but it is measured in relative terms.

The country's export potential has been measured through RCA. It shows the trade potential of the country by which the country extends the export product. RCA can give very helpful information regarding the prospects of potential trade with new partners. There are very less chances of having bilateral trade between the countries having alike RCA profiles until and unless there is an involvement in intra industry trade. The attention through 
RCA measures can be given to other non-traditional goods that might be effectively exported. For commodity $h$ the RCA index is calculated by share of commodity $h$ of India export in respect to total share of commodity $h$ in world export.

Table 1. India's Top Importer Countries

(In US Thousand dollar)

\begin{tabular}{|c|c|c|c|c|}
\hline $\begin{array}{c}\text { HS } \\
\text { Code }\end{array}$ & Products & & Top Countries & \\
\hline 01 & Live Animals & Nepal- $\$ 31,024$ & $\begin{array}{l}\text { United Arab } \\
\text { Emirates- } \$ 23,986\end{array}$ & Bangladesh- $\$ 5638$ \\
\hline 02 & Meat & $\begin{array}{l}\text { Vietnam- } \\
\$ 3,723,988\end{array}$ & $\begin{array}{l}\text { Malaysia- } \\
\$ 1,785,416\end{array}$ & Indonesia- $\$ 365,123$ \\
\hline 03 & Fish etc. & USA- $\$ 2,003,438$ & $\begin{array}{l}\text { Vietnam- } \\
\$ 1,173,820\end{array}$ & China- $\$ 565,842$ \\
\hline 04 & Dairy products etc. & USA- $\$ 93,036$ & UAE- $\$ 43,154$ & Egypt- $\$ 44,770$ \\
\hline 05 & Products of animal origin & Vietnam- $\$ 59,516$ & Myanmar- $\$ 29,609$ & China- $\$ 8,970$ \\
\hline 06 & Live trees & USA- $\$ 19,822$ & Netherlands- $\$ 11,532$ & $\begin{array}{l}\text { United Kingdom- } \\
\$ 6,905\end{array}$ \\
\hline 07 & Edible vegetable etc. & $\begin{array}{l}\text { United Arab } \\
\text { Emirates-\$145,107 }\end{array}$ & Sri Lanka-\$100,086 & Malaysia-\$93,969 \\
\hline 08 & Edible fruits; and nuts & $\begin{array}{l}\text { United Arab } \\
\text { Emirates-\$281,443 }\end{array}$ & $\begin{array}{l}\text { Netherlands- } \\
\$ 207,358\end{array}$ & Saudi Arab- $\$ 142,001$ \\
\hline 09 & Coffee and spices etc & Vietnam- $\$ 334,093$ & USA- $\$ 315,439$ & Italy- $\$ 168,830$ \\
\hline 10 & Cereals & Iran, $-\$ 1,200,515$ & $\begin{array}{l}\text { Saudi Arab- } \\
\$ 1,011,820\end{array}$ & $\begin{array}{l}\text { United Arab } \\
\text { Emirates- } \$ 1,200,515\end{array}$ \\
\hline 11 & Products of milling industry & USA- $\$ 60,594$ & UAE- $\$ 33,657$ & Malaysia- $\$ 30,387$ \\
\hline 12 & $\begin{array}{l}\text { Oil seeds, miscellaneous } \\
\text { grains etc. }\end{array}$ & USA- $\$ 239,939$ & Indonesia- $\$ 215,678$ & Vietnam- $\$ 139,828$ \\
\hline 13 & Lac; gums; resins & USA- $\$ 499,036$ & China- $\$ 83,238$ & Germany- $\$ 48,389$ \\
\hline 14 & Vegetables plaiting materials & Japan- $\$ 8,809$ & China- $\$ 7,670$ & Sri Lanka-\$7,119 \\
\hline 15 & Animal, vegetables oils & China- $\$ 409,119$ & $\begin{array}{l}\text { Netherlands- } \\
\$ 141,488\end{array}$ & USA- $\$ 116,137$ \\
\hline 16 & $\begin{array}{l}\text { Preparation of meat. And other } \\
\text { aquatic invertebrates }\end{array}$ & USA- $\$ 321,851$ & Canada- $\$ 30,456$ & Belgium- $\$ 10,287$ \\
\hline 17 & Sugar and sugar confectionery & Sudan- $\$ 216,054$ & Myanmar- $\$ 130,646$ & Sri Lanka- $\$ 98,298$ \\
\hline 18 & Cocoa and cocoa preparations & USA- $\$ 46,490$ & Turkey- $\$ 18,721$ & Indonesia- $\$ 17,679$ \\
\hline 19 & $\begin{array}{l}\text { Preparations of cereals, flour } \\
\text { etc. }\end{array}$ & USA- $\$ 88,791$ & Nepal- $\$ 50,334$ & Bangladesh- $\$ 40,581$ \\
\hline 20 & $\begin{array}{l}\text { Preparation of vegetables, } \\
\text { fruits etc. }\end{array}$ & USA- $\$ 111,082$ & $\begin{array}{l}\text { Netherlands- } \\
\$ 58,487\end{array}$ & UK- $\$ 47,856$ \\
\hline 21 & $\begin{array}{l}\text { Miscellaneous edible } \\
\text { preparations }\end{array}$ & USA- $\$ 150,357$ & UAE- $\$ 48,793$ & $\begin{array}{l}\text { Russia Federation- } \\
\$ 47,063\end{array}$ \\
\hline 22 & Beverages, spirits and vinegar & UAE- $\$ 85,399$ & Singapore- $\$ 32,378$ & Nigeria- $\$ 20,690$ \\
\hline 23 & $\begin{array}{l}\text { Residues, waste of food } \\
\text { industries }\end{array}$ & Vietnam- $\$ 157,186$ & $\begin{array}{l}\text { Bangladesh- } \\
\$ 209,953\end{array}$ & Korea- $\$ 154,516$ \\
\hline 24 & $\begin{array}{l}\text { Tobacco and manufactured } \\
\text { tobacco substitutes }\end{array}$ & Belgium- $\$ 150,709$ & UAE- $\$ 138,260$ & Afghanistan- $\$ 92,316$ \\
\hline \multicolumn{5}{|c|}{$\begin{array}{l}\text { Source: Calculations are based on the database of International Trade Centre (ITC), Geneva, Switzerland. } \\
\text { Table 2. India's Top Exporter Countries } \\
\text { (In US Thousand dollar) }\end{array}$} \\
\hline $\begin{array}{c}\text { HS } \\
\text { Code }\end{array}$ & Products & & Top Countries & \\
\hline
\end{tabular}




\begin{tabular}{|c|c|c|c|c|}
\hline 01 & Live animal & U.S.A $-\$ 3,418$ & U.K-\$2,639 & France $-\$ 2,597$ \\
\hline 02 & Meat & Belgium $-\$ 1,188$ & $\begin{array}{l}\text { New Zealand- } \\
\$ 1,167\end{array}$ & Spain - \$648 \\
\hline 03 & Fish etc. & $\begin{array}{l}\text { Vietnam - } \\
\$ 23,915\end{array}$ & U.S.A. $-\$ 18,801$ & Bangladesh- $\$ 15,838$ \\
\hline 04 & Dairy products etc. & France - $\$ 10,347$ & Italy $-\$ 3,349$ & Germany $-\$ 2,938$ \\
\hline 05 & Products of animal origin & U.S.A. $-\$ 30,851$ & Belgium - $\$ 6,273$ & Tunisia - $\$ 2,411$ \\
\hline 06 & Live trees & $\begin{array}{l}\text { Netherlands-- } \\
\$ 6,912\end{array}$ & Thailand $-\$ 6,048$ & Italy $-\$ 3,260$ \\
\hline 07 & Edible vegetable etc. & $\begin{array}{l}\text { Myanmar- } \\
\$ 293,201\end{array}$ & Canada $-\$ 112,761$ & $\begin{array}{l}\text { Mozambique- } \\
\$ 104,143\end{array}$ \\
\hline 08 & Edible fruits; and nuts & USA - \$887,627 & $\begin{array}{l}\text { Cote d lvoire - } \\
\$ 329,225\end{array}$ & Benin $-\$ 276,494$ \\
\hline 09 & Coffee and spices etc & $\begin{array}{l}\text { VietNam- } \\
\$ 233,848\end{array}$ & $\begin{array}{l}\text { Sri Lanka- } \\
\$ 93,709\end{array}$ & Madagascar- $\$ 80,310$ \\
\hline 10 & Cereals & $\begin{array}{l}\text { Argentina- } \\
\$ 24,529\end{array}$ & Australia- $\$ 13,079$ & $\begin{array}{l}\text { Russian Federation - } \\
\$ 10,575\end{array}$ \\
\hline 11 & Products of milling industry & China $-\$ 19,255$ & Australia- $\$ 17,412$ & Sri Lanka - \$11,274 \\
\hline 12 & $\begin{array}{l}\text { Oil seeds, miscellaneous grains } \\
\text { etc. }\end{array}$ & Sudan $-\$ 103,863$ & Turkey - \$51,475 & Ethiopia - \$31,853 \\
\hline 13 & Lac; gums; resins & $\begin{array}{l}\text { Afghanistan- } \\
\$ 103,489\end{array}$ & Indonesia-\$17,953 & USA $-\$ 17,776$ \\
\hline 14 & Vegetables plaiting materials & China $-\$ 30,622$ & Nepal - \$6,057 & Indonesia $-\$ 3,931$ \\
\hline 15 & Animal, vegetables oils & $\begin{array}{l}\text { Indonesia- } \\
\$ 3,775,301\end{array}$ & $\begin{array}{l}\text { Ukraine-- } \\
\$ 1,850,978\end{array}$ & Argentina- $\$ 1,604,839$ \\
\hline 16 & $\begin{array}{l}\text { Preparation of meat. And other } \\
\text { aquatic invertebrates }\end{array}$ & $\begin{array}{l}\text { Sri Lanka - } \\
\$ 1,491\end{array}$ & China - $\$ 643$ & Spain - \$613 \\
\hline 17 & Sugar and sugar confectionery & Brazil - $\$ 566,048$ & $\begin{array}{l}\text { Netherlands- } \\
\$ 23,057\end{array}$ & Germany- $\$ 21,963$ \\
\hline 18 & Cocoa and cocoa preparations & $\begin{array}{l}\text { Indonesia- } \\
\$ 69,245\end{array}$ & $\begin{array}{l}\text { Cote d lvoire-- } \\
\$ 21,191\end{array}$ & Singapore- $\$ 20,987$ \\
\hline 19 & Preparations of cereals, flour etc. & $\begin{array}{l}\text { Thailand-- } \\
\$ 14,568\end{array}$ & $\begin{array}{l}\text { Singapore-- } \\
\$ 10,901\end{array}$ & Malaysia- $\$ 10,542$ \\
\hline 20 & $\begin{array}{l}\text { Preparation of vegetables, fruits } \\
\text { etc }\end{array}$ & China $-\$ 25,282$ & Thailand- $\$ 10,954$ & U.S.A - \$10,768 \\
\hline 21 & Miscellaneous edible preparations & U.S.A - $\$ 94,138$ & China $-\$ 16,764$ & Vietnam $-\$ 10,897$ \\
\hline 22 & Beverages, spirits and vinegar & U.S.A - $\$ 255,410$ & U.K - \$197,103 & Singapore- $\$ 70,464$ \\
\hline 23 & Residues, waste of food industries & $\begin{array}{l}\text { Sri Lanka- } \\
\$ 87,637\end{array}$ & Thailand- $\$ 65,800$ & Vietnam - $\$ 63,551$ \\
\hline 24 & $\begin{array}{l}\text { Tobacco and manufactured } \\
\text { tobacco substitutes }\end{array}$ & Serbia $-\$ 9,979$ & $\begin{array}{l}\text { Zimbabwe- } \\
\$ 6,544\end{array}$ & Germany $-\$ 4,837$ \\
\hline
\end{tabular}

Source: Calculations are based on the database of International Trade Centre (ITC), Geneva, Switzerland.

\section{India's Agriculture Trade Performance}

The modern revolutions and technological reforms in Indian agriculture were led by green revolution, leading increase in agriculture production, particularly in the food grains. This had a beneficial for India's exports. Initially, India was a net importer of food grains, after that India has shift to being a net exporter of agriculture commodities due to new economic policy (NEP). Figure 1 demonstrate the agriculture trade balance grow positively after introducing NEP in 1990-91 and growing after that. 


\section{India's Agriculture trade performance}

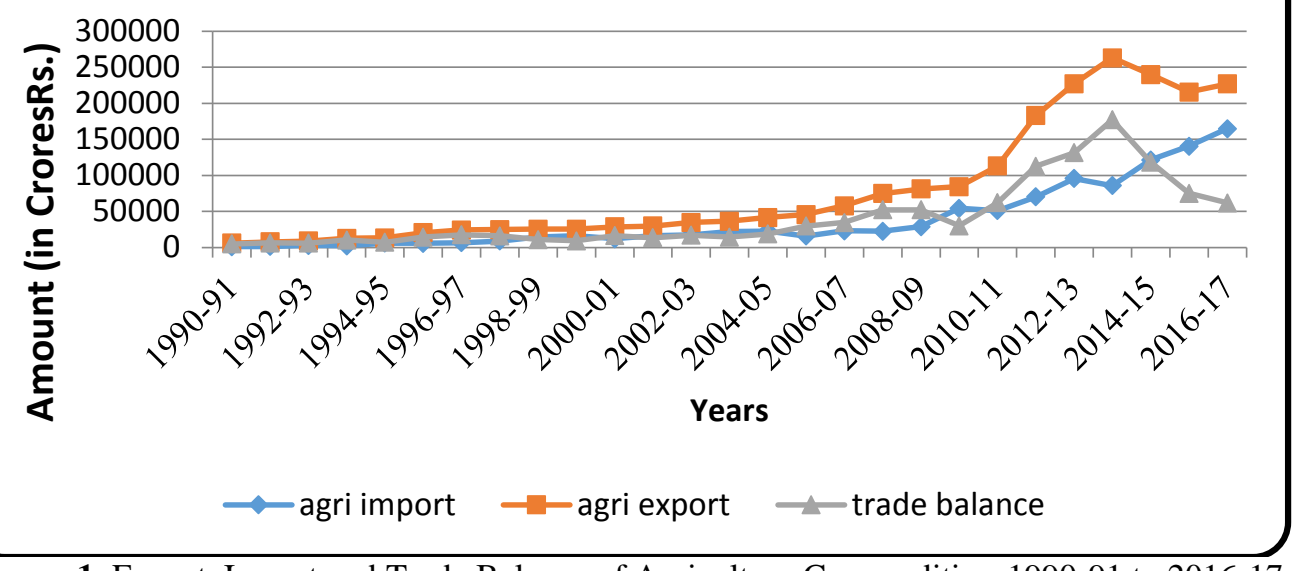

Figure 1. Export, Import and Trade Balance of Agriculture Commodities, 1990-91 to 2016-17

During the phase of LPG (Liberalization, Privatization and Globalization), the export of agriculture commodities was of Rs. 6,012.76 Crores and contributed 18.49 percent of total national exports, while imports was of Rs. 1,205.86 Crores, i.e. 2.79 percent of total national imports. Thus, there was agriculture trade surplus of Rs. 4,806.9 Crores. In 1996-97, agriculture export increased by more than four times, reaching Rs. 24,161.29, and import increased by approximately six times to Rs. 6,612.6 Crores with respect to 1990-91 and the trade surplus was raised by four times to Rs. 17,548.69 Crores. In 2000-01 there was surplus in agriculture trade of Rs. 16,571.14 Crores. During the period of six years i.e. from 2000-01 to 2006-07, the agriculture export increased by more than Rs. 25,000 Crores and reached Rs. 57,767.87 Crores and import increased by more than Rs. 10,000 Crores to reach Rs. 23,000.28 Crores. The Indian Government, in 2010 removed the restriction on export of wheat and after that the agriculture exports increased drastically. During 2000 to 2017, the agriculture export was highest in 2013-14 which estimated around Rs. 262,778.54 Crores. Agriculture export of Rs. 226,651.94 Crores and import of Rs. 164,726.83 Crores and trade balance stood at Rs. 61,925.11 Crores in 2016-17.

Table 2. Track Record of Indian Agricultural Exports, 2001-2018.

\begin{tabular}{llllll}
\hline & \multicolumn{6}{l}{ Share } \\
\cline { 2 - 7 } \multicolumn{1}{c}{ Commodities } & $\mathbf{2 0 0 1}$ & $\mathbf{2 0 0 5}$ & $\mathbf{2 0 1 0}$ & $\mathbf{2 0 1 3}$ & $\mathbf{2 0 1 8}$ \\
\hline 1. Meat & 4.4 & 6 & 9.2 & 11.2 & 9.6 \\
2. Fish, etc. & 19.8 & 15.2 & 11.3 & 11.8 & 16.4 \\
3. Dairy products etc. & 1.2 & 2.5 & 1.2 & 1.7 & 1.2 \\
4. Edible vegetables, etc. & 3.8 & 5.6 & 5 & 3.3 & 3.1 \\
5. Edible fruits: and nuts & 8.7 & 9 & 5.7 & 3.9 & 4.1 \\
6. Coffee and spices etc. & 13.2 & 9.3 & 10.4 & 6.8 & 8.1 \\
7. Cereals & 14.4 & 19.9 & 15.2 & 27.1 & 20.1 \\
8. Oilseeds & 5.1 & 4.2 & 5.7 & 4.4 & 4.1 \\
9. Lac, resins & 3.8 & 4.2 & 3.4 & 7.2 & 2.8 \\
10. Animal, vegetable oils & 3.1 & 3.3 & 3.7 & 2.3 & 2.8 \\
11. Sugar & 5.7 & 0.8 & 5.4 & 2.8 & 3.1 \\
12. Residues & 7.2 & 8.4 & 10.8 & 8.7 & 4.4 \\
\hline 13. Miscellaneous commodities & 9.8 & 11.5 & 13 & 9 & 20.2 \\
\hline
\end{tabular}

Source: The calculations are based on the database of International Trade Centre (ITC), Geneva, Switzerland.

There are 24 HS Code agricultural commodities (01-24).12 out of 24 were taken separately and remain others were taken combined as miscellaneous commodities.

\section{Role of WTO in Trade Expansion}

There is an international institution- World Trade Organization (WTO), who watches over the global trade rules among nations.Out of world's trading nations', majority have signed the agreement of the WTO. Giving protection and help the exporters, importers and manufacturers to manage their businesses is the main function of WTO. A platform is provided by WTO which allows member nations to settle trade disputes among other 
member nation. When the trade issues among the nations are solved, then there can be smooth trade between the countries which can even increase the trade amongst them.

WTO states the ideology of ideal trade as follows:

- Non-Discriminatory- It means that WTO restricts a member of it to informally trade freely with one country and imposing heavy trade restrictions on some other country, all being WTO's members.

- Free from barriers (Protectionism) - They believe that the trade should be free as much as possible with less protectionism.

- Predictable- In order to foster the economy with which the investment decisions can take place, the business can prosper and jobs can be created well, trade should be predictable.

- $\quad$ Promoting fair competition- There needs to be fair trade between the nations.

- Favorable for developing countries through special regulations.

\section{Roles of WTO}

- To place and to impose regulations on international trade- If the members of WTO are violates the rules of WTO, then they can be punished.

- To settle trade issues-WTO works as a middle man to solve the disputes where if a country imposes higher tariffs on another country, the grieved country should not do the same thing with that or other country.

- To provide an environment for negotiating trade liberalization- WTO provides a platform and may organize a forum for the countries who wishes to have a trade deal which is quicker and easier than the countries doing it by themselves.

- To observe further trade liberalization- WTO ensures that if a free trade agreement is signed, then the trade actually happening is free.

- To give benefits of global trade to developing countries.

When the countries would see that the WTO is performing its functions and roles properly to prevent the developing and undeveloped countries to get exploited by the developed countries in trade, they will be tend to smoothly trade and thus would trade more. Thus it will lead to expansion of trade.

\section{World Trade Organization- Agreement on Agriculture}

The WTO Agreement on Agriculture was negotiated during the Uruguay Round in 1993, which was formally ratified in 1994. The Agreement on Agriculture was implemented with effect from 1.1.1995. The provisions of the Agreement stated that in 6 years and 10 years, the reduction commitments of the developed and developing countries respectively would be completed by 2000 and 2004 respectively, whereas least developed countries were not required to make any reductions.

\section{Salient Features}

The Agreement contains provisions in 3 different broad fields of agriculture and trade policy: market access, domestic support and export subsidies. Market Access- it includes the provisions of tarrification of all non-tariff barrier, access opportunities and tariff reduction. Tariffication is when all non-tariff barriers like minimum import prices, quotas, discretionary licensing etc. are eliminated and changed into an equivalent tariff. All the tariffs either ordinary or those which results from tariffication are to be reduced by an average 36 percent with least rate of reduction of 15 percent for each item under tariff over a 6 year period for developed countries. Developing countries were supposed to trim down tariffs in 10 years by 24 percent. Developing countries, who were maintaining Quantitative Restrictions (a GATT measure) owing to the problems of balance of payment, were permitted to put forward ceiling bindings in place of tariffication. For domestic support provisions, question to reduction commitments, the total support provided in 1986-88, measured by the Total Aggregate Measure of Support, should be decreased by 20 percent and 13.3 percent in developed and developing countries respectively. Reduction commitments were meant for total levels of support and not for individual merchandise. Export Subsidies is regarding the members' commitment to reduce Export subsidies. The export subsidy expenditure is required to reduce by 36 percent and volume by 21 percent over 6 years in equal installments by the developed countries whereas for developing countries, it was necessary to decrease their export subsidy expenses by 24 percent and volume by 14 percent in 10 years.

No direct subsidies for agricultural commodities are provided to the exporters of India. They get subsidies in the following forms-

a) There is no income tax implemented on Agriculture, so they get exemption in the income tax on profit 
via export.

b) Subsidies on charge of freight on export delivery of certain goods such as floricultural products, vegetables and fruits.

\section{Findings}

\section{Balassa's Revealed Comparative Advantage Index (RCA)}

In 1965, Balassa gave the concept of Balassa's index of Revealed Comparative Advantage (RCA). The Balassa's Index reveals that the nation is potential of exporting certain agricultural products in which the RCA of the country is more than or equivalent to 1 . It means that the country can focus on the export of these goods instead of exporting the goods which have RCA value less than 1 . The factors that contribute to movements in RCA are economic: structural change, improved world demand and trade specialization.

Table 3. The Value of RCA for Agricultural Products (Broad category-wise) when RCA $<1$ India has comparative disadvantage in the products as shown in table 3.

\begin{tabular}{lll}
\hline 2 Digit HS Code & \multicolumn{1}{c}{ Commodity Name } & RCA Value<1 \\
\hline 01 & Live animals & 0.082 \\
22 & Beverages & 0.159 \\
06 & Live trees & 0.216 \\
18 & Cocoa & 0.233 \\
04 & Dairy produces & 0.319 \\
19 & Preparations of cereals & 0.403 \\
16 & Preparation of meat, and other aquatic invertebrates & 0.481 \\
20 & Fruits. & 0.544 \\
21 & Miscellaneous edible preparations & 0.585 \\
05 & Products of animal origin & 0.701 \\
15 & Animal fatsand oils, etc. & 0.712 \\
08 & Edible fruits and nuts & 0.740 \\
11 & Products of the milling industry & 0.930 \\
12 & Oil seeds, miscellaneous grains, etc. & 0.962 \\
\hline 07 & Edible vegetables etc. & 0.983 \\
\hline
\end{tabular}

Source: The calculations are based on the database of International Trade Centre (ITC), Geneva, Switzerland.

Indian government should make policies such that these goods should not be encouraged for exports as exporting these would be a disadvantage for the country because it will consume more resources and would cost more. Instead, the country should import these goods and focus on the goods in which RCA is greater than 1 as shown in table 4.

Table 4: The Value of RCA for Agricultural Products (Broad Category-Wise) when RCA>1 In following products India has comparative advantage.

\begin{tabular}{lll}
\hline 2 Digit HS Code & \multicolumn{1}{c}{ Commodity Name } & RCA Value>1 \\
\hline 23 & Residues & 1.258 \\
24 & Tobacco & 1.290 \\
17 & Sugars & 1.651 \\
02 & Meat & 1.737 \\
14 & Vegetable plaiting materials & 2.759 \\
03 & Fish and other aquatic invertebrates & 3.035 \\
09 & Coffee and spices etc. & 3.749 \\
10 & Cereals & 4.129 \\
\hline 13 & Lac; gums; resins & 7.775 \\
\hline
\end{tabular}

Source: The calculations are based on the database of International Trade Centre (ITC), Geneva, Switzerland.

India should export more of the goods as shown in table 4 as the value of RCA is more than 1 . The resources that are available in the country are suitable for the production of the above goods and it will be suitable to export these goods. The government should encourage the producers to produce more of these goods as well as encourage exporters to export these goods. India should produce the commodities like HS10 (Cereals), HS13 (Lac; gums and resins) and so on which have a greater RCA value. The advantage of this will be that India would 
produce it cheaply as compared to other countries and in good quantity which will result in the inflow of foreign currency which would give little relief in current account deficit.

Table 5. The value of RCA for Agricultural Products (Sub-Category-Wise)

The underlying table shows the revealed comparative advantage and disadvantage in the 4 digit HS code.

\begin{tabular}{|l|l|l|l|}
\hline 4 Digit HS Code & RCA Value & 4 Digit HS Code & RCA Value \\
\hline 1003 & 0.012 & 208 & 0 \\
\hline 1008 & 2.407 & 210 & 0.006 \\
\hline 1007 & 1.716 & 201 & 0.122 \\
\hline 1005 & 0.449 & 202 & 8.111 \\
\hline 1004 & 0.004 & 205 & 0 \\
\hline 1006 & 16.868 & 204 & 0.862 \\
\hline 1002 & 0 & 203 & 0.862 \\
\hline 1001 & 0.067 & 209 & 0 \\
\hline 308 & 0.185 & 906 & 0.51 \\
\hline 306 & 9.198 & 907 & 0.763 \\
\hline 304 & 0.642 & 901 & 1.014 \\
\hline 305 & 0.864 & 910 & 8.695 \\
\hline 302 & 0.127 & 903 & 0.001 \\
\hline 303 & 1.676 & 908 & 6.658 \\
\hline 301 & 0.044 & 904 & 12.478 \\
\hline 307 & 3.258 & 909 & 30.807 \\
\hline 206 & 1.609 & 902 & 5.845 \\
\hline 207 & 0.018 & 905 & 0.736 \\
\hline
\end{tabular}

Source: The calculations are based on the database of International Trade Centre (ITC), Geneva, Switzerland. Detailed description about 4 digit HS Code commodity can be taken directly from ITC

India should export some commodities in which RCA is greater than 1 which are HS1006 (Rice), HS0910 (Ginger, saffron, turmeric and others), HS0909 (Seeds of anis, badian, fennel and others), HS0902 (Tea), and few others. India should export more of the products of HS0909 because it has the greatest RCA value which is 30.807 more than any of the agricultural goods. The demand of Indian rice in international market is higher comparing to other nations, thus the RCA value of rice is 16.86 which allows India to export it more.

There are few other goods in table 5 which has comparative disadvantage in exporting of those goods as the RCA value of it is less than 1. These goods are HS0903 (Mate), HS0905 (Vanilla), HS0907 (Cloves, whole fruits and others) and so on. The government should not encourage the exporters to export these goods.

\section{Conclusion}

This study shows that, country has comparative advantage in exporting some goods such as rice, tea, coffee, some spices, tobacco, sugar, meat and others, while comparative disadvantage in exporting other goods such as some spices, barley, fish, maize, wheat, edible fruits and nuts and so on. From table 1, we can see that India exports to both developing and developed countries with highest exports of agricultural goods to USA. Vietnam is India's largest importer of edible meat offal.

Fish and other aquatic invertebrates and spices, tea, Coffee and mate have shown significant growth in 2018 comparing to 2013 as shown in table 2 with their share in agricultural exports being 16.4 and 8.1 respectively. We have seen in the study that what measures WTO takes in order to ease out the facilities of trade expansion which are helpful for the developing and underdeveloped nations to remain unexploited by the strong nations. In the study, we can see that in 2013-14, the export of India is highest and fluctuating thereafter. We can also see that the agriculture import has been drastically increasing since 2013 . This has led the agriculture trade balance decrease drastically.

\section{Suggested Policies}

Our study has recommended that government should increase the exports of agriculture products by providing the exporters subsidies through development banks and EXIM banks so that the exported agricultural products become cheaper for the exporter and is encouraged to export it more. Government should regulate the Foreign Trade Policies (FTP) so that the exporters are incentivized to export the agricultural products. Farmers of 
the country should be well trained, monetized and unexploited so that they produce better quality products. The government should promote private players in this sector.

\section{References}

12. Amarnath, T., \& Prasad, A.R. (2009). Agriculture Development in India since Independence: A Study on Progress, Performance and Determinant. Journal of Emerging Knowledge on Emerging Markets, 1 .

13. Ansari, S.A., \& Khan, W. (2015). India's Agricultural Trade Potential in Post-WTO Period. Agricultural Economics Research Review, 28(347-2016-17214), 93-100.

14. APEDA (Agricultural \& Processed Food Products Export Development Authority) (various years) www.apeda.gov.in

15. Balassa, B. (1965). Trade liberalisation and revealed comparative advantage 1. The Manchester school, 33(2), 99-123.

16. Batra, A., \& Khan, Z. (2005). Revealed comparative advantage: An analysis for India and China (No. 168). Working paper.

17. Byerlee, D, De Janvry, A., \& Sadoulet, E. (2009). Agriculture for development: Toward a new paradigm. Annu. Review of Resource Economics, 1(1), 15-31.

18. India.gov.in

19. Ingco, M., \& Sh, J.D. (Eds.). (2004). Agriculture and the WTO: creating a trading system for development. The World Bank.

20. International Trade Centre (ITC) database, Geneva, Switzerland. Agrilture \& Farmers

21. MANAGE (National Instituted of Agriculture Extension Management) https://www.manage.gov.in/studymaterial/WTO.pdf

22. Ministry of Agriculture and Farmer's Welfare, Department of Agriculture.

23. Panchamukhi, V.R. (1986). Trade in agricultural commodities: Analysis of the period 19601985. Indian Agricultural Development Since Independence, A Collection of Essays.

24. Utkulu, U., \& Seymen, D. (2004). Revealed Comparative Advantage and Competitiveness: Evidence for Turkey vis-à-vis the EU/15. In European trade study group 6th annual conference, ETSG, 1-26.

25. World Bank, Washington, D.C., United States.

26. World Integrated Trade Solution. 